\title{
一般固有值問題におけるランチョス逆べキ乗法による スパース対称行列の中間固有対の一算定法 \\ A METHOD FOR DETERMINING INTERMEDIATE EIGENPAIRS OF SPARSE, SYMMETRIC MATRICES BY LANCZOS AND SHIFTED INVERSE POWER METHOD IN GENERALIZED EIGENVALUE PROBLEMS
}

\author{
柏木光博* \\ Mitsuhiro KASHIWAGI
}

\begin{abstract}
This paper presents a useful numerical calculation method based on the Lanczos and shifted inverse power method in the intermediate eigenpair of sparse and symmetric matrices. The proposed method has a good accuracy and stability in a relatively small computational time. The obtained results agree well with the exact solutions in short CPU time. From these, the present method may be said to provide an efficient approach in the process of the Lanczos and shifted inverse power method
\end{abstract}
Keywords : Generalized eigenvalue problems, Sparse and symmetric matrices, Preconditioned Conjugate gradient method, Intermediate eigenpairs, Lanczos and inverse power method 一般固有值問題, スパース対称行列, 前処理付共役勾配法, 中間固有対, ランチョス逆ベキ乗法

\section{1. はじめに}

ICCG 法や SCG 法等の共役勾配法系の反復法 (PCG 法) $)^{1,2,4,7,8,15,16,22)}$ は，直接法に比べ主記憶領域を極めて少なくできるため，スパース な行列に対して有力な解析手段となる. スパース性を固有值問題に 活か寸ためには, ベキ乗法系解法やランチョス法系解法などの反復 法系解法 2, 9, 10,11,12,13,14, 16, 18, 19,20,21, 22) に頼らざるを得ない. ベキ乗法 3,18) 系解法は，固有值の小さい方あるいは大きい方からいくつかの 固有対（固有值と対応する固有ベクトル）を求め得る。スパース対 称行列用固有值問題に対して有効なランチョス法 ${ }^{2,6,18)}$ やブロック ランチョス法 ${ }^{5,6)}$ は行列の 3 重対角化を可能とし, ベキ乗法系解法 と同様に最小あるいは最大固有值近辺のいくつかの固有対を求め得 る. リスタート・ランチョス法 ${ }^{2)}$ は部分空間の固有值解析を繰り返 すことによって固有対を得る方法であり，現在では，最小あるいは 最大固有值近辺のいくつかの固有対を求める問題に利用されている. ランチョス法などの Krylov 部分空間に基づく反復法 ${ }^{2,19,21)}$ に代わ る有効な方法として Jacobi- Davidson 法 ${ }^{20,21)}$ があるが, 有限要素 解析における固有值問題に対する有効性が検討されている ${ }^{22)}$.

ある物体にそれとは異なる物体を載せたり, 繋いだりなどした場 合，それぞれの物体の固有值がほぼ同じ時に共振状態になる可能性 がある．その共振状態を避けるためには中間の固有值を知る必要が あり, 設計上の重要なチェックポイントとなる. 逆ベキ乗法やサブ
スペース法およびリスタート・ランチョス法などの反復系解法は, 最小固有值や最大固有值からいくつかの固有値を求める場合に有効 であるが，任意の中間の原点移動点付近の固有值解析には解析不能 や解の見落としを呈する。固有值解析は非常に大きな計算負荷を伴 うので，ある固有值近辺の固有対を多くても何十か求めれば効率的 な設計ができるものと思われる。

シフト逆ベキ乗法（原点移動逆ベキ乗法）は原点移動量を適切に 設定すると，原点移動していない場合に比べ，収束を速くする効果 を期待できる，古典的方法ではあるが，反復法系のシフト逆ベキ乗 法は，任意の中間の原点移動点付近の固有值解析に有効な方法と思 われる。ただし，最小固有值と最大固有值のほぼ中間の原点移動点 付近の行列は特に悪条件となり, 反復回数と計算時間は極端に多く なる. 最近，柏木は共役勾配法系の反復法や原点移動逆ベキ乗法を 利用しながら，スパース行列で任意の中間のいくつかの固有対を求 めるダブルシフト逆ベキ乗法を提案した ${ }^{12,13)}$. そこでは原点移動量 の適切な設定值を示し，SCG 法などの前処理を施した共役勾配法系 の反復法を利用しながら，スパース行列で特に任意の中間の固有対 をいくつか求める場合に有効であることを示した.

本論文はスパース対称行列の任意の中間の原点移動点付近の固有 対を求める 1 方法を提案している. リスタート・ランチョス法にお いて, 求める固有対を全て含んだ部分空間の固有值問題を繰り返し

\footnotetext{
$*$ 東海大学産業工学部建築学科 教授 $\cdot$ 工博
} Prof., Dept. of Architecture, School of Industrial Engineering, Tokai Univ., Dr. Eng. 
解いた著者の数值実験では, 最小固有值付近の固有対をいくつか求 める場合, あるいは最大固有值付近の固有対をいくつか求める場合 に効果的であるが，ある中間固有值付近の固有対をいくつか求める 時には解の見落としをする場合や仮定した最大反復回数で求まらな い場合が生じた。提案法の特徵は, 反復の途中で得られる近似固有 ベクトルのレーリー商とそれに対応する残差ベクトルのノルムを用 いて固有值の存在範囲を推定し, その存在範囲を基に原点移動量を 決定する方法およびランチョス法による部分空間固有值問題を原点 移動点に最も近い固有值の収束に特化することにより計算時間の短 縮化と結果の安定性を保つことが出来ることである. 特に係数行列 の要素の単位が異なり, 要素の絶対值の差が大きい場合に計算効率 が高い結果を得た。提案法によって, 対象とする行列の原点移動点 に最も近い固有值から順次計算できる. ダブルシフト逆べキ乗法と 同様に, SCG 法などの前処理を施した共役勾配法系の反復法を利用 しながら，スパース行列で特に任意の中間の固有対をいくつか求め る場合に有効である. 提案法で最大固有值から数個の固有対を求め る場合も，逆べキ乗法で最小固有值から数個の固有対を求める場合 と同様に数值解析できるのも特徵である. また, 提案法による数值 実験では，解の見落としをする場合や仮定した最大反復回数で求ま らない場合は生じなかった

以下に，ランチョス逆ベキ乗法などのアルゴリズムを述べると共 に, 標準固有值問題および一般固有值問題に関する数値実験により, その有効性を示す.

\section{2. ランチョス逆ベキ乗法のアルゴリズム}

反復法系の中間固有值算定法は限られており，その中でも有効な 解法は，シフト逆ベキ乗法とダブルシフト逆ベキ乗法であることを 柏木は示したが, 様々な工夫を施した提案のランチョス逆べキ乗法 は上述のシフト逆ベキ乗法より収束性は良く, また, ダブルシフト 逆べキ乗法と同程度かそれ以上の解法である. 逆べキ乗法系の固有 值解析は反復毎に連立 1 次方程式を解くので, 計算時間は連立 1 次 方程式の解析回数に依存する. よって, 収束性が良いほど反復回数 は少なく計算時間は短い. シフト逆ベキ乗法とダブルシフト逆べキ 乗法およびランチョス逆べキ乗法の収束性を比較しながら, それぞ れの方法の特徴について記す。シフト逆べキ乗法は古典的方法では あるが，任意の原点移動点付近の固有值解析に適した方法である. ただし, 最小固有值と最大固有值のほぼ中間の固有值の場合, 他の 2 解法に比べ反復回数と計算時間は極端に多くなる傾向を示寸. 収 束性の極端に悪い計算対象では，下記のアルゴリズムに示すように 最大反復回数を本数值実験では 10 万回と多くしなくてはならなか った。また，対象によっては収束しない場合もある。しかし，ここ での数值実験では解の見落としはなく安定した解法であった。ダブ ルシフト逆ベキ乗法は反復毎に原点移動量を適切に設定できるので, シフト逆ベキ乗法より計算時間を短くできる. 固定原点移動の場合 に比べ収束を速くする効果があるので, 最大反復回数も本数值実験 では 3 万回とシフト逆べキ乗法より少なくできる. ランチョス逆べ キ乗法は部分空間のランチョス法を何回も反復処理し収束性を良く した方法であり, 本数值実験では, 一つの固有対を求めるためには, 最大で $11 \times 11=121$ 回の SCG 法による連立 1 次方程式の解析と最 大で 11 回の 3 重対角行列（11 次元）の固有值問題の解析を行えば
良いので収束性がよい. よって, 計算時間も短縮化される。また, ここでの収束判定值については，今までの多くの固有值解析に対す る論文や数值実験を参考にして決定した.

以下に，シフト逆ベキ乗法とダブルシフト逆ベキ乗法およびラン チョス逆ベキ乗法のアルゴリズムの詳細を示す。これらのアルゴリ ズムにより数值実験を行った。

\section{1 主な記号}

$\lambda$ : 固有値

$\lambda_{0}:$ 原点移動量

$A: n \times n$ 実対称行列（剛性行列）

$B: n \times n$ 正定值対称行列（質量行列あるいは幾何剛性行列）

標準固有值問題では， $B=I$ (単位行列) と置く

$x$ : 固有ベクトル

$\left[A-\lambda_{0} B\right] x=\left(\lambda-\lambda_{0}\right) B x$ : 一般固有值問題

$\ell$ : 反復回数

$\lambda^{(\ell)}: \ell$ 反復時近似固有值

$x^{(\ell)}: \ell$ 反復時近似固有ベクトル

$r^{(\ell)}=A x^{(\ell)}-\lambda^{(\ell)} B x^{(\ell)}: \ell$ 反復時残差ベクトル

\section{2 シフト逆ベキ乗法}

(1) $\ell=0$

初期ベクトル $x^{(0)}$ を一様乱数によって生成する. 最大反復回数を 設定する．グラム・シュミットの方法により，既に得られた $i$ 個 の固有ベクトル $\phi$ の抜き取りと正規化および初期近似固有值を次 式で求める.

$$
\begin{aligned}
& \widetilde{x}^{(0)}=x^{(0)}-\sum_{j=1}^{i}\left(x^{(0)^{T}} B \phi_{j}\right) \phi_{j}, \quad x^{(0)}=\widetilde{x}^{(0)} /\left(\widetilde{x}^{(0)^{T}} B \widetilde{x}^{(0)}\right)^{\frac{1}{2}}, \\
& \lambda^{(0)}=x^{(0)^{T}} A x^{(0)}
\end{aligned}
$$

(2) $\ell=1,2, \cdots$

シフト逆ベキ乗法による反復計算を行う.

(1) $\ell$ 反復時での $x^{(\ell)}$ は, $x^{(\ell)}=\left[A-\lambda_{0} B\right]^{-1} B x^{(\ell-1)}$ によって求める. グラム・シュミットの方法により，既に得られた固有ベクトル の抜き取りと正規化および近似固有值を次式で求める.

$$
\begin{aligned}
& \tilde{x}^{(\ell)}=x^{(\ell)}-\sum_{j=1}^{i}\left(x^{(\ell)^{T}} B \phi_{j}\right) \phi_{j}, \quad x^{(\ell)}=\tilde{x}^{(\ell)} /\left(\tilde{x}^{(\ell)^{T}} B \tilde{x}^{(\ell)}\right)^{\frac{1}{2}}, \\
& \lambda^{(\ell)}=x^{(\ell)^{T}} A x^{(\ell)}
\end{aligned}
$$

(2) 収束判定を行う. 最大反復回数（本数值実験では $\ell_{\text {max }}=100000$ ）を超えたら計算をストップ。 $\varepsilon_{1}$ と $\varepsilon_{2}$ を収束 判定值とすると $\left|\frac{\lambda^{(\ell)}-\lambda^{(\ell-1)}}{\lambda^{(\ell)}}\right|<\varepsilon_{1} \quad\left(\right.$ 本数值実験では $\left.\varepsilon_{1}=10^{-14}\right)$ あるいは，残差ベクトル $r^{(\ell)}$ を計算し

$$
\left.\frac{\left\|r^{(\ell)}\right\|}{\left\|A x^{(\ell)}\right\|}<\varepsilon_{2} \quad \text { (本数值実験では } \varepsilon_{2}=10^{-8}\right)
$$

であれば収束．次の固有值を求める場合，(1)に戻るが，求め ない場合，（3）へ，収束していない場合，（2）の(1)に戻る，

（3）最後に, 求められた全ての固有值と固有ベクトルに対して，固 有值と固定原点移動量 $\lambda_{0}$ との差の絶対值が小さい方から順に 
並び替えを行う。

\section{3 ダブルシフト逆ベキ乗法}

(1) $\ell=0$

初期ベクトル $x^{(0)}$ を一様乱数によって生成する. 最大反復回数を 設定する. グラム・シュミットの方法により, 既に得られた $i$ 個 の固有ベクトル $\phi$ の抜き取りと正規化および初期近似固有值を次 式で求める.

$\tilde{x}^{(0)}=x^{(0)}-\sum_{j=1}^{i}\left(x^{(0)^{T}} B \phi_{j}\right) \phi_{j}, \quad x^{(0)}=\widetilde{x}^{(0)} /\left(\tilde{x}^{(0)^{T}} B \widetilde{x}^{(0)}\right)^{\frac{1}{2}}$,

$\lambda^{(0)}=x^{(0)^{T}} A x^{(0)}$

(2) $\ell=1,2, \cdots$

(1) $\ell$ 反復時での $x^{(\ell)}$ は $x^{(\ell)}=\left[A-\lambda_{0} B\right]^{-1} B x^{(\ell-1)}$ によって求める. グ ラム・シュミットの方法により, 既に得られた固有值ベクトル の抜き取りと正規化および近似固有值を次式で求める。 $\lambda_{0}$ は 初期原点移動量のままである.

$\tilde{x}^{(\ell)}=x^{(\ell)}-\sum_{j=1}^{i}\left(x^{(\ell)^{T}} B \phi_{j}\right) \phi_{j}, \quad x^{(\ell)}=\widetilde{x}^{(\ell)} /\left(\widetilde{x}^{(\ell)^{T}} B \tilde{x}^{(\ell)}\right)^{\frac{1}{2}}$,

$\lambda^{(\ell)}=x^{(\ell)^{T}} A x^{(\ell)}$

(2) 原点移動（シフト）判定を行う. 最大反復回数（本数值実験で は $\ell_{\max }=30000 ）$ を超えたら計算をストップ.

$\left|\frac{\lambda^{(\ell)}-\lambda^{(\ell-1)}}{\lambda^{(\ell)}}\right|<\varepsilon_{e}$ であれば逐次原点移動量 $\lambda_{0}^{(\ell)}$ を求め (2) の (3)

へ、満足しなければ(2)の(1)に戻る。ここに， $\varepsilon_{e}$ は固有值の同 次シフト時相対誤差值であり, 本数值実験では,

$\varepsilon_{e}=\min \left(10^{-1} /\left(\lambda_{0}+1\right), 10^{-5}\right)$ とした.

(3)収束判定を行う． $\varepsilon_{1}$ と $\varepsilon_{2}$ を収束判定值とすると

$$
\left|\frac{\lambda^{(\ell)}-\lambda^{(\ell-1)}}{\lambda^{(\ell)}}\right|<\varepsilon_{1} \quad\left(\text { 本数值実験では } \varepsilon_{1}=10^{-14}\right)
$$

あるいは，残差ベクトル $r^{(\ell)}$ を計算し

$$
\frac{\left\|r^{(\ell)}\right\|}{\left\|A x^{(\ell)}\right\|}<\varepsilon_{2} \quad\left(\text { 本数值実験では } \varepsilon_{2}=10^{-8}\right)
$$

であれば収束. 次の固有值を求める場合，(1)に戻るが，求めな い場合，(3)へ．収束していない場合，以下の式によって $\lambda_{0}^{(\ell+1)}$ 計算し，（2）の(1)に戻る.

$\rho=\left|\lambda^{(\ell)}-\lambda^{(\ell-1)}\right|, \quad g=\left\{r^{(\ell)}\right\}^{T} B^{-1} r^{(\ell)}, \quad \beta^{(\ell)}=\rho g /\left(\rho^{2}-g\right)$,

$\lambda_{0}^{(\ell+1)}=\lambda^{(\ell)}-\beta^{(\ell)}$

(3) 最後に, 求められた全ての固有値と固有ベクトルに対して, 固有 值と固定原点移動量 $\lambda_{0}$ との差の絶対值が小さい方から順に並び 替えを行う。

\section{4 ランチョス逆ベキ乗法}

ランチョス法による 3 重対角化を第 $m$ 段で打ち切った時, $m$ 個の
基底ベクトル $y_{k}$ を列とする $n \times m$ 行列 $Y_{m}=\left[y_{1}, y_{2}, \cdots, y_{m}\right]$ と，

$m \times m$ の 3 重対角行列 $T_{m}=\left[\begin{array}{ccccc}\alpha_{1} & \beta_{1} & & & \\ \beta_{1} & \alpha_{2} & \beta_{2} & & \\ & \ddots & \ddots & \ddots & \\ & & & & \beta_{m-1} \\ & & & \beta_{m-1} & \alpha_{m}\end{array}\right]$ が得られる.

以下に本論文で提案するアルゴリズムを示す

(1) $\ell=0$

初期ベクトル $x^{(0)}$ を一様乱数によって生成する. 最大反復回数を 設定する．グラム・シュミットの方法により，既に得られた $i$ 個 の固有ベクトル $\phi$ の抜き取りと正規化および初期近似固有值を次 式で求める。

$\tilde{x}^{(0)}=x^{(0)}-\sum_{j=1}^{i}\left(x^{(0)^{T}} B \phi_{j}\right) \phi_{j}, \quad x^{(0)}=\widetilde{x}^{(0)} /\left(\widetilde{x}^{(0)^{T}} B \widetilde{x}^{(0)}\right)^{\frac{1}{2}}$,

$\lambda^{(0)}=x^{(0)^{T}} A x^{(0)}$

次に, $y_{1}=x^{(0)}$ とする.

(2) $\ell=1,2, \cdots$

部分空間シフト用ランチョス法による反復計算を行う.

(1) $\alpha_{1}=y_{1}^{T} B\left[A-\lambda_{0} B\right]^{-1} B y_{1} \quad\left(\left[A-\lambda_{0} B\right]^{-1} B y_{1}\right.$ の計算後, このベクト ルから既に得られた $i$ 個の固有ベクトル $\phi$ の抜き取りを行う) $z_{1}=\left[A-\lambda_{0} B\right]^{-1} B y_{1}-\alpha_{1} y_{1} \quad, \quad \beta_{1}=\left(z_{1}^{T} B z_{1}\right)^{\frac{1}{2}} \quad, \quad y_{2}=z_{1} / \beta_{1}$ を 計算する。

(2) $\quad \alpha_{k}=y_{k}^{T} B\left[A-\lambda_{0} B\right]^{-1} B y_{k} \quad\left(\left[A-\lambda_{0} B\right]^{-1} B y_{k}\right.$ の計算後, このベクト ルから既に得られた $i$ 個の固有ベクトル $\phi$ 抜き取りを行う) , $z_{k}=\left[A-\lambda_{0} B\right]^{-1} B y_{k}-\beta_{k-1} y_{k-1}-\alpha_{k} y_{k} \quad, \quad \beta_{k}=\left(z_{k}^{T} B z_{k}\right)^{\frac{1}{2}}$ を計算 する.

(3) ここで従来のランチョス逆ベキ乗法の計算過程に以下の計算手 順を取り入れて，最小固有值から中間固有值をはさんで最大固 有值まで安定した解が求められるアルゴリズムを考える。 $k$ が計算個数 $m$ （本数值計算では $m=11 ）$ に達すれば(2)の(4)へ. そうでなければ $y_{k+1}=z_{k} / \beta_{k}$ を計算し，(2)の(2)に戻る.

(4) $T_{m} Q_{m}=Q_{m} \Pi_{m}$ なる部分空間固有值問題をとく.ここに, $Q_{m}$ は $Q_{m}=\left[q_{1}, q_{2}, \cdots, q_{m}\right]$ を， $\Pi_{m}$ は $\Pi_{m}=\operatorname{diag}\left[\pi_{1}, \pi_{2}, \cdots, \pi_{m}\right]$ を表し ている.

(5) $\lambda=\frac{1}{\pi}+\lambda_{0}, x=Y_{m} q$ により近似固有値, 近似固有ベクトル を求める. 求められた全ての近似固有值と近似固有べクトルに 対して, 近似固有值と固定原点移動量 $\lambda_{0}$ との差の絶対值が小さ い方から順に並び替えを行う。

(6) 近似固有值と固定原点移動量 $\lambda_{0}$ との差の絶対值が最も小さ い1番目の固有值に対して収束判定を行う.

$\left|\frac{\lambda^{(\ell)}-\lambda^{(\ell-1)}}{\lambda^{(\ell)}}\right|<\varepsilon_{1} \quad\left(\right.$ 本数值実験では $\left.\varepsilon_{1}=10^{-14}\right)$ 
あるいは残差ベクトル： $r^{(\ell)}$ を計算し

$\frac{\left\|r^{(\ell)}\right\|}{\left\|A x^{(\ell)}\right\|}<\varepsilon_{2} \quad$ (本数值実験では $\left.\varepsilon_{2}=10^{-8}\right)$

であれば収束．次の固有值を求める場合，（1）に戻るが，求め ない場合，（4)へ，収束していない場合，（2）の(1)に戻るが， 部分空間シフト用ランチョス法による反復計算がある回数（本 数值実験の (2)では， $\ell_{\max }=11$ ) を超えた場合，（3）に進む．こ の時, 初期逐次シフト值を 1 番目の固有值 $\lambda_{0}^{(\ell-1)}$ にする. また, $y_{1}$ を $x_{1}$ とする.

(3) 逐次シフト逆ベキ乗法による反復計算を行う.

(1) $\ell$ 反復時での $x^{(\ell)}$ は $x^{(\ell)}=\left[A-\lambda_{0}^{(\ell-1)} B\right]^{-1} B x^{(\ell-1)}$ によって求める. グラム・シュミットの方法により, 既に得られた固有值ベクト ルの抜き取りと正規化および近似固有值を次式で求める。 $\lambda_{0}$ は初期原点移動量のままである.

$$
\begin{aligned}
& \tilde{x}^{(\ell)}=x^{(\ell)}-\sum_{j=1}^{i}\left(x^{(\ell)^{T}} B \phi_{j}\right) \phi_{j}, \quad x^{(\ell)}=\tilde{x}^{(\ell)} /\left(\tilde{x}^{(\ell)^{T}} B \tilde{x}^{(\ell)}\right)^{\frac{1}{2}}, \\
& \lambda^{(\ell)}=x^{(\ell)^{T}} A x^{(\ell)}
\end{aligned}
$$

(2)収束判定を行う. 最大反復回数（本数值実験の (3) では $\ell_{\text {max }}=1000$ ）を超えたら計算をストップ. $\varepsilon_{1}$ と $\varepsilon_{2}$ を収束判定值と すると

$\left|\frac{\lambda^{(\ell)}-\lambda^{(\ell-1)}}{\lambda^{(\ell)}}\right|<\varepsilon_{1} \quad$ (本数值実験では $\left.\varepsilon_{1}=10^{-14}\right)$

あるいは，残差ベクトル： $r^{(\ell)}$ を計算し

$\frac{\left\|r^{(\ell)}\right\|}{\left\|A x^{(\ell)}\right\|}<\varepsilon_{2} \quad$ (本数值実験では $\left.\varepsilon_{2}=10^{-8}\right)$

であれば収束. 収束していない場合, 以下の式によって $\lambda_{0}^{(\ell)}$ 計算し，(3)の(1)に戻る.

$$
\begin{aligned}
& \rho=\left|\lambda^{(\ell)}-\lambda^{(\ell-1)}\right|, \quad g=\left\{r^{(\ell)}\right\}^{T} B^{-1} r^{(\ell)}, \quad \beta^{(\ell)}=\rho g /\left(\rho^{2}-g\right), \\
& \lambda_{0}^{(\ell+1)}=\lambda^{(\ell)}-\beta^{(\ell)}
\end{aligned}
$$

(4) 最後に, 求められた全ての固有值と固有ベクトルに対して, 固有 值と固定原点移動量 $\lambda_{0}$ との差の絶対值が小さい方から順に並び 替えを行う.

\section{3. 数值実験}

ランチョス逆ベキ乗法における有効性を示すために, 標準固有值 問題および一般固有值問題に関する例題による数值実験を行った. ここでの数值実験は, すべて倍精度演算とした. 求める固有対の個 数は 10 個とした. 先述のアルゴリズムに従った. 計算には, 今回は スーパーコンピューターを対象としていないこと, および最近のパ ーソナルコンピューターの性能向上などを考慮し, ' Intel (R) Core $^{\mathrm{MM}}$ i7 3. 2GHz, RAM12. 0 GB, Windows 7, PGI Fortran Workstation (pgiwsx64-106)' を使用した. また, 解析時に必要となる連立方程 式の解法として反復法（SCG 法）を利用した. ICCG 法や SCG 法など の前処理を施した共役勾配法系の反復法は，スパース行列に有効で あるが，ICCG 法は中間固有対に対し不安定な性状を示し, SCG 法よ り計算時間が多かったのでここでは省いた，以下に詳細を記す。

\section{1 標準固有値問題(ヘルムホルツ問題)}

ここでは，2次元波動方程式の定常問題におけるへルムホルツ方 程式を離散化して生じる倸数マトリックスを扱った。この固有值問 題では固有值の解析解が分かっており, 数值実験時に求められた固 有值の精度について検証できる対象となっている．また，多くの多 重根や極近接根をもつ求めにくい対象でもある。自由度と原点移動 量を変化させながら数值実験した。

以下のようなヘルムホルツ 2 次元モデルを考える（図 1)。境界条 件は境界值を 0 とする。ヘルムホルツ方程式に中心差分を用いて離 散化を行うと, $A x=\lambda x$ の固有值問題が得られる.ここで, $A=\left(a_{k, l}\right)$ とおけば, 係数行列 $A$ の各要素は次式となる.

$a_{l, l}=\frac{2}{\Delta x^{2}}+\frac{2}{\Delta y^{2}}, \quad l=(i-1) n_{y}+j \quad, \quad\left(1 \leq i \leq n_{x}, 1 \leq j \leq n_{y}\right)$,

$a_{l, l+n y}=a_{l+n y, l}=-\frac{1}{\Delta x^{2}}, \quad l=(i-1) n_{y}+j \quad, \quad\left(1 \leq j \leq n_{x}, 1 \leq j<n_{y}\right) ，$

$a_{l, l+1}=a_{l+1, l}=-\frac{1}{\Delta y^{2}}, \quad l=(i-1) n_{y}+j \quad, \quad\left(1 \leq i<n_{x}, 1 \leq j \leq n_{y}\right)$,

$a_{l, m}=0 \quad$ 上記以外の $l, m$

ここで, $\Delta x=l_{x} /\left(n_{x}+1\right), \quad \Delta y=l_{y} /\left(n_{y}+1\right)$ はそれぞれ $x, y$ 方向の分割 幅である.この係数行列 $A$ の固有值の解析解は次式で与えられる.

$$
\lambda_{i, j}=\frac{2}{\Delta x^{2}}\left(1-\cos \frac{i \pi}{n_{x}+1}\right)+\frac{2}{\Delta y^{2}}\left(1-\cos \frac{j \pi}{n_{y}+1}\right)
$$

数值実験に用いたパラメータ $l_{x}, l_{y}, n_{x}, n_{y}, n=n_{x} \times n_{y}$ を表 1 に示す また，表 2 にそれぞれのタイプ毎の初期原点移動量を示す（表 3 の 最小固有值と最大固有值を考慮して初期原点移動量を決めているが, 本法では任意に設定できる)。左端に示す $\lambda_{0}$ は最小固有值以下を， 右端に示す $\lambda_{0}$ は最大固有值以上を採用している. 全モデルについて の不正解数 (上記の解析解と提案法による解析結果との相対誤差值 が $10^{-9}$ 以上を不正解とする）は 0 であった。表 4 は提案法（LN） によるそれぞれのタイプ毎の最大相対誤差值を示しているが，最も 大きいところで $0.952 \times 10^{-12}$ であり，良好な精度を示した．SCG 法 の最大反復回数は自由度の 3 倍とした.

図-2〜6 は，表-1のモデルAの 5 タイプについて，シフト逆ベキ 乗法（IP）とダブルシフト逆ベキ乗法（DS）およびランチョス逆べ キ乗法（LN）の計算時間を描いている。図毎の上図は 3 解法の計算 時間を比較しているが，下図はDS と LN の計算時間を描いている.

IP で計算する場合，ある中間固有值近辺 10 個に対する計算時間 のそれぞれのタイプの最大倍率は 85〜1092 倍であり, 中間固有值を 求める時の計算時間は甚大である。中間固有值を求める場合がいか に高負荷であるかが分かる．ランチョス逆ベキ乗法では，最大固有 值付近以外は，部分空間シフト・ランチョスのアルゴリズムだけで 解が求められる場合が多く, 最大固有值付近ではシフト逆べキ乗法 で収束していた。図からも分かるように，ランチョス逆ベキ乗法と ダブルシフト逆ベキ乗法の計算時間はシフト逆ベキ乗法に比べ格段 に計算効率は高い。また，ランチョス逆ベキ乗法の計算時間はダブ ルシフト逆ベキ乗法と比べ殆ど変わらないが，最小固有值近辺以外 はほぼダブルシフト逆ベキ乗法より短く，計算効率は若干良い。 

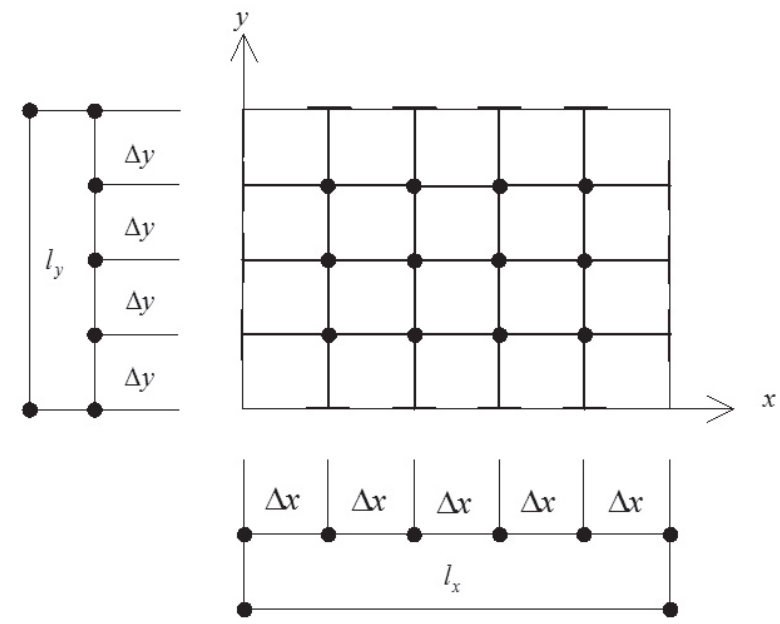

図 12 次元モデルの一例

表 12 次元モデルのパラメーター

\begin{tabular}{|c|c|c|c|c|c|c|}
\hline \multirow{2}{*}{ model } & type & $l_{x}$ & $l_{y}$ & $n_{x}$ & $n_{y}$ & $n$ \\
\hline \multirow{4}{*}{$\mathrm{A}$} & $\mathrm{A}-1$ & 1 & 1 & 50 & 50 & 2500 \\
\cline { 2 - 7 } & $\mathrm{A}-2$ & 1 & 1 & 100 & 100 & 10000 \\
\cline { 2 - 7 } & $\mathrm{A}-3$ & 1 & 1 & 150 & 150 & 22500 \\
\cline { 2 - 7 } & $\mathrm{A}-4$ & 1 & 1 & 200 & 200 & 40000 \\
\cline { 2 - 7 } & $\mathrm{A}-5$ & 1 & 1 & 250 & 250 & 62500 \\
\hline
\end{tabular}

表 22 次元モデルの初期原点移動量

\begin{tabular}{|c|c|c|c|c|c|c|}
\hline type & \multicolumn{6}{|c|}{$\lambda_{0}$} \\
\hline A-1 & 0 & 5000 & 10000 & 15000 & 20000 & 25000 \\
\hline A-2 & 0 & 20000 & 40000 & 60000 & 80000 & 100000 \\
\hline A-3 & 0 & 40000 & 80000 & 120000 & 160000 & 200000 \\
\hline A-4 & 0 & 70000 & 140000 & 210000 & 280000 & 350000 \\
\hline A-5 & 0 & 110000 & 220000 & 330000 & 440000 & 550000 \\
\hline
\end{tabular}

表 32 次元モデルの最小固有值と最大固有值

\begin{tabular}{|c|c|c|}
\hline type & 最小固有值 & 最大固有值 \\
\hline$A-1$ & 19.73296782 & 20788.26703 \\
\hline A-2 & 19.73761736 & 81588.26238 \\
\hline$A-3$ & 19.73849679 & 182388.2615 \\
\hline$A-4$ & 19.73880696 & 323188.2612 \\
\hline$A-5$ & 19.73895111 & 503988.2610 \\
\hline
\end{tabular}

表 4 タイプ毎の解析解との最大相対残差值

\begin{tabular}{|c|c|}
\hline type & 最大相対残差值 \\
\hline $\mathrm{A}-1$ & $0.668 \times 10^{-13}$ \\
\hline $\mathrm{A}-2$ & $0.409 \times 10^{-13}$ \\
\hline $\mathrm{A}-3$ & $0.351 \times 10^{-13}$ \\
\hline $\mathrm{A}-4$ & $0.298 \times 10^{-12}$ \\
\hline $\mathrm{A}-5$ & $0.952 \times 10^{-12}$ \\
\hline
\end{tabular}
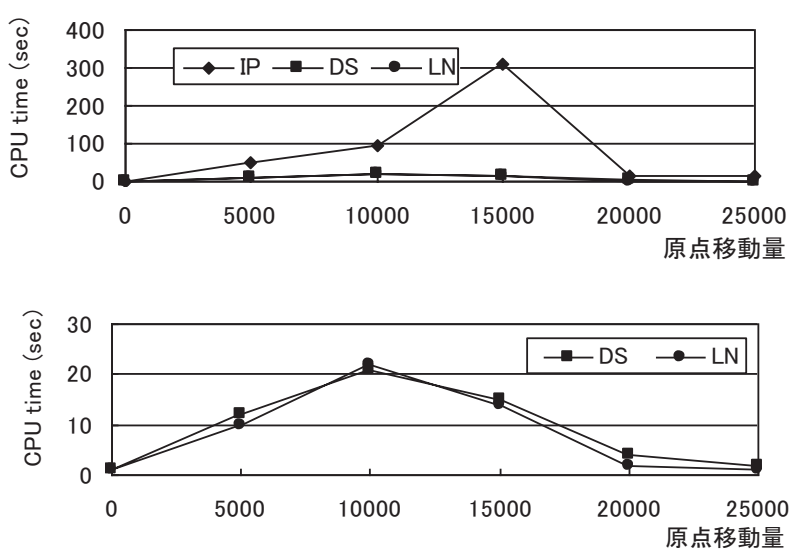

図 2 計算時間 ( 2 次元モデル, タイプA-1)
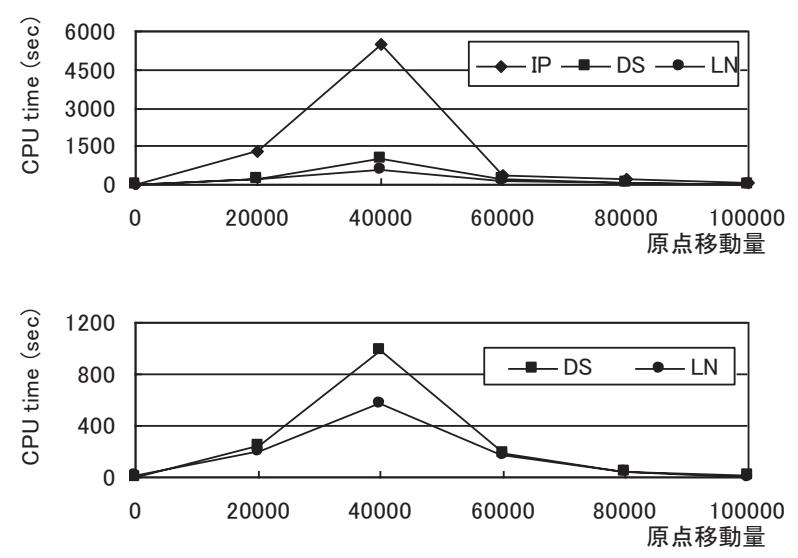

図 3 計算時間 ( 2 次元モデル, タイプA-2)
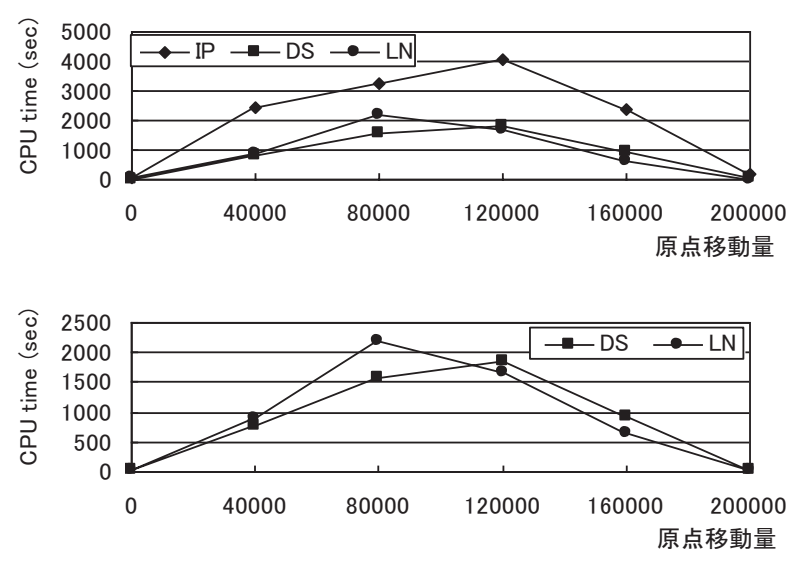

図 4 計算時間（2 次元モデル，タイプ A-3)

\section{2 一般固有値問題(平面骨組問題)}

ここでは, 図 7 のような平面骨組問題で生じる係数行列を扱った. 骨組の柱と梁は鉄筋コンクリート製で，両方共ヤング率は $20.58 \mathrm{GN} / \mathrm{m}^{2}$ とした。柱と梁の断面（幅×高さ）はそれぞれ $0.8 \mathrm{~m} \times$ $0.8 \mathrm{~m}$ と $0.4 \mathrm{~m} \times 0.8 \mathrm{~m}$ である. 部材長（階高とスパン長）はそれぞれ 3 $\mathrm{m}$ と $6 \mathrm{~m}$ にした. 骨組の各節点は自由度 $3(\mathrm{x}$ 方向変位 $\mathrm{u}, \mathrm{y}$ 方向変 位 $\mathrm{v}$ ，たわみ角 $\theta$ ）を有しており，作成された係数（剛性）行列は dimension の異なる, それぞれの要素の大きさに差がある対象とな っている。 また, 本例題は, 最大固有值に近づくにつれ近接固有值 

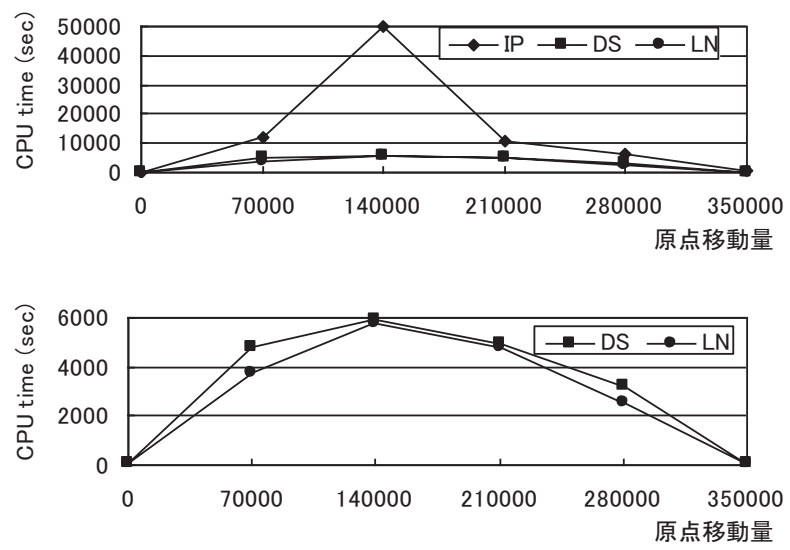

図 5 計算時間 $(2$ 次元モデル, タイプ $\mathrm{A}-4)$
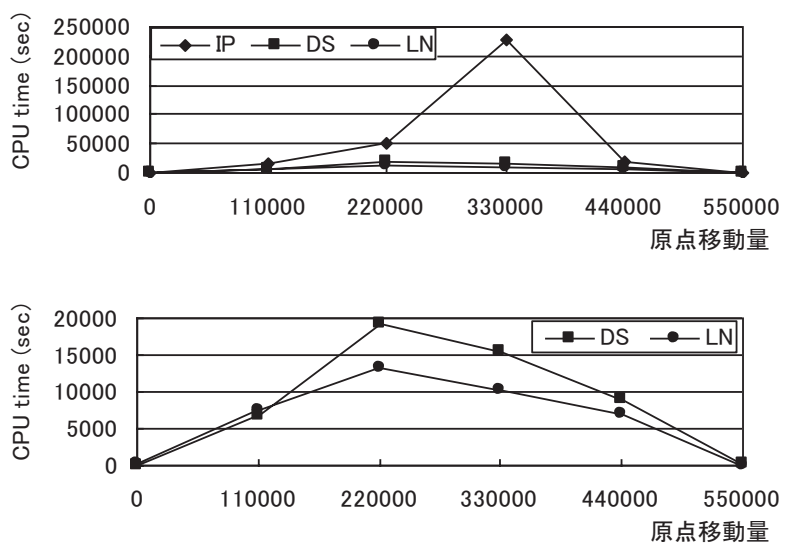

図 6 計算時間 $(2$ 次元モデル, タイプ $\mathrm{A}-5)$

や極近接固有值が多数存在する対象である. 自由度（表 5）と原点 移動量（表 6) を変化させ数值実験した（表 7 の最小固有值と最大 固有值を考慮して初期原点移動量を決めているが, 本法では任意に 設定できる). 左端に示す $\lambda_{0}$ は最小固有值以下を, 右端に示す $\lambda_{0}$ は 最大固有值以上を採用している. 全モデルについての不正解数（シ フト逆べき乗法で原点移動量付近の固有值を 30 個解析した結果と 提案法による解析結果との相対誤差值が $10^{-9}$ 以上を不正解と寸る) は 0 であった. SCG 法の最大反復回数は自由度の 3 倍とした.また, SCG 法において利用した対角要素は, $\lambda_{0} B$ を減じない元の対角要素 を利用した。

ここでの数値実験における行列 $B$ (質量行列) は, consistent mass matrix である.ただし， $B^{-1} r$ の計算は，標準固有值問題では $B=I$ のため, 提案法での連立 1 次方程式で解く回数は倍にならないが, 一般固有值問題では $B y=r$ を解くことになり, 提案法での連立 1 次 方程式で解く回数は倍になる. しかし， $B^{-1} r$ の計算は原点移動量を 求めるためだけで本質的な問題でないこと, および, lumped mass matrix でも近似的に十分なものであることを考慮し, 平面骨組にお ける lumped mass matrix を使用した ${ }^{17)}$ 。よって， $B^{-1} r$ 計算用の $B$ matrix は対角行列となり, 提案法での連立 1 次方程式で解く回数 は倍にならない, 以下に, この数值実験で使用した平面骨組用 element lumped mass matrix を示す.

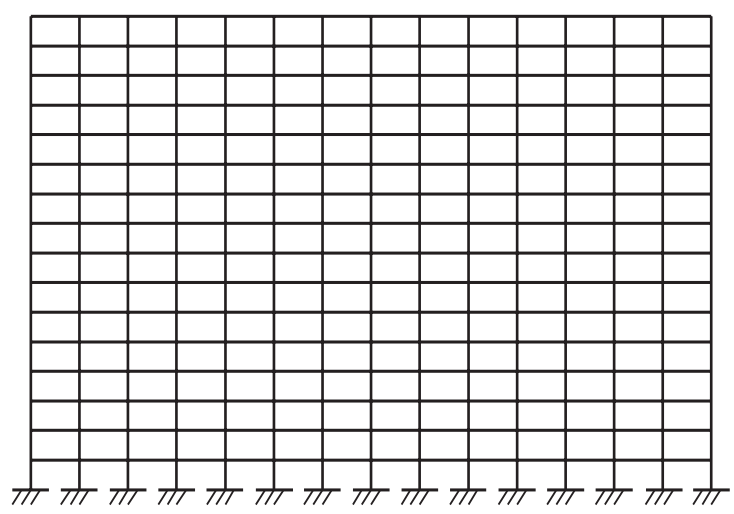

図 7 平面骨組モデルの一例

表 5 平面骨組モデルのパラメーター

\begin{tabular}{|c|c|c|c|c|}
\hline model & type & $m r$ & $n r$ & $n$ \\
\hline \multirow{2}{*}{ B } & B-1 & 16 & 14 & 720 \\
\cline { 2 - 5 } & B-2 & 32 & 29 & 2880 \\
\cline { 2 - 5 } & B-3 & 48 & 44 & 6480 \\
\hline
\end{tabular}

$m r$ : numbers of story, $n r:$ numbers of span, $n:$ degrees of freedom

表 6 平面骨組モデルの初期原点移動量 $\left(\lambda_{0}\right)$

\begin{tabular}{|c|l|l|l|l|}
\hline type & \multicolumn{4}{|c|}{$\lambda_{0}$} \\
\hline B-1,2,3 & 0 & 2500 & 5000 & 7500 \\
\hline
\end{tabular}

表 7 平面骨組の最小固有值と最大固有值

\begin{tabular}{|c|c|c|}
\hline type & 最小固有值 & 最大固有值 \\
\hline B-1 & 0.06544565874 & 7043.922569 \\
\hline B-2 & 0.01599910744 & 7081.771233 \\
\hline B-3 & 0.007700032715 & 7089.754261 \\
\hline
\end{tabular}

$$
\bar{B}=\frac{\rho \bar{A} \ell}{2}\left[\begin{array}{ccccccc}
1 & & & & & \\
& 1 & & & 0 & \\
& & \frac{\ell^{2}}{210} & & & \\
& & & 1 & & \\
& 0 & & & 1 & \\
& & & & & \frac{\ell^{2}}{210}
\end{array}\right]
$$

$\bar{B}$ : element lumped mass matrix, $\rho$ :density,

$\bar{A}$ : cross-section area, $\ell$ : length of element

図 8〜10 は, 表 5 のモデルBの 3 タイプについて, シフト逆ベキ 乗法（IP）とダブルシフト逆ベキ乗法（DS）およびランチョス逆べ キ乗法（LN）の計算時間を描いている。また, 図毎の上図は 3 解法 の計算時間を比較しているが，下図はDSとLNの計算時間を描いて いる. IP で計算する場合，ある中間固有值近辺 10 個に対する計算 時間のそれぞれのタイプの最大倍率は 72 亿 377 倍であり, 中間固有 值を求める時の計算時間は標準固有值問題の数值実験結果と同様に 


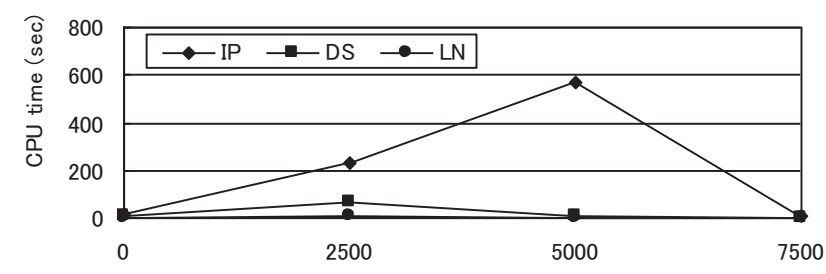

原点移動量

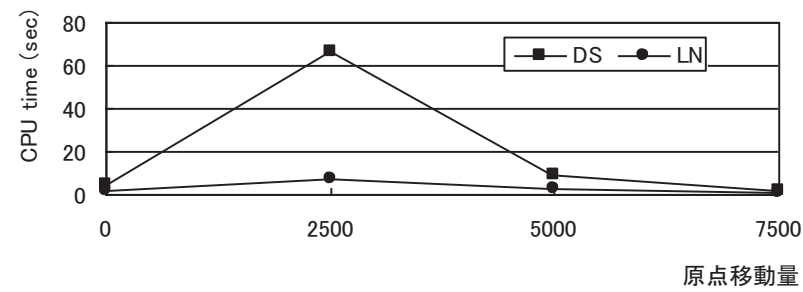

図 8 計算時間（平面骨組モデル，タイプ B-1）
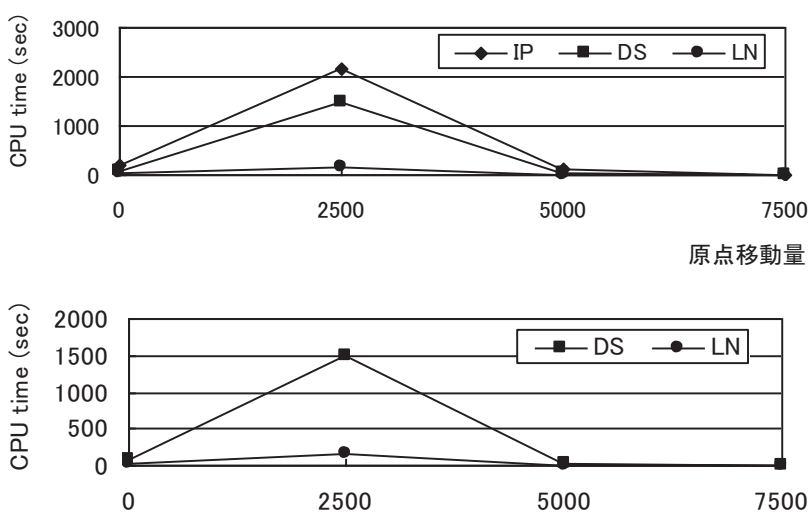

原点移動量

図 9 計算時間 (平面骨組モデル，タイプ B-2)
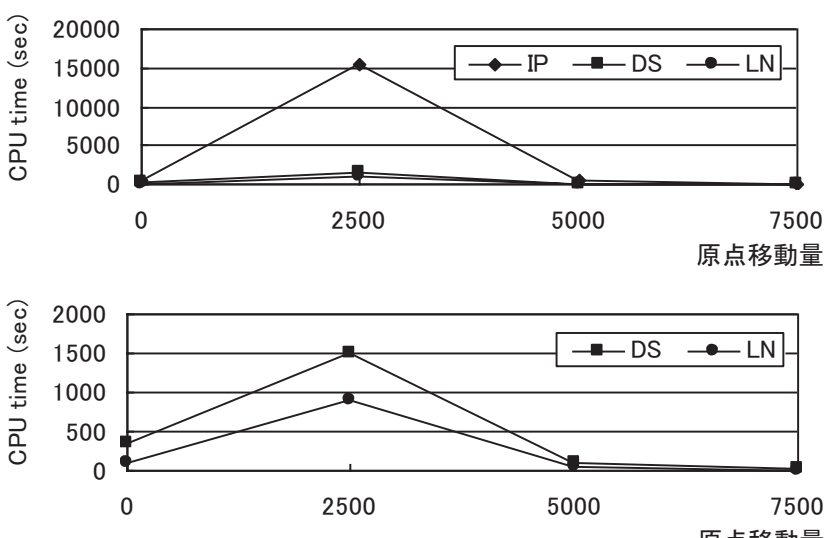

図 10 計算時間（平面骨組モデル，タイプ B-3）

甚大である. 中間固有値を求める場合がいかに高負荷であるかが分 かる. 図からも分かるように, ランチョス逆ベキ乗法とダブルシフ 卜逆ベキ乗法の計算時間はシフト逆ベキ乗法に比べ格段に計算効率 は高い。また，ランチョス逆べキ乗法の計算時間はダブルシフト逆 ベキ乗法より短く(typeB-1 で 1/2〜1/9.4, type B-2 で 1/1. 3〜 1/9.9, type B-3で1/1.7〜1/3.3), ランチョス逆ベキ乗法はダブルシフト 逆ベキ乗法より計算効率は高い.

\section{4. 結び}

構造物の大規模化や細分化は構造解析時の行列次数を大次元化し ており, 構造解析における連立 1 次方程式の解法は, バンド型やス カイライン型による直接法から SCG 法や ICCG 法等の反復法に依存す る方向にある. 動的解析や大变形解析に見られる固有值問題も同様 である. 中間固有值を求める場合は計算負荷が非常に大きい問題 (最 小固有值近辺を求める場合の何十倍から何百倍）となる. 古典的原 点移動逆べキ乗法は，ここでの数值実験では不正解数は 0 で安定し た解法となっているが，提案法より計算負荷が大きい．ランチョス 逆ベキ乗法とダブルシフト逆べキ乗法は，最小固有值から中間固有 值を挟んで最大固有值まで，安定して解を求めることができ，記憶 容量を少なくして大次元まで考慮でき，そして計算時間を短くでき る解法であると思われる。また，パラレル計算機に適合するアルゴ リズムをもつ SCG 法を利用できることはパラレル化に対しても有効 となる.

本数值実験から，提案のランチョス逆ベキ乗法は，特に中間固有 対を求める場合, 計算負荷を小さくし, 安定的に解を求め得る解法 である，ただし，今後，古典的な解法で不正解を得るモデル，特に 工学で発生するモデルや大次元による検証の追試が必要であると考 える.

謝辞

数々の有益なご意見をご指摘いただきました査読者の方々に感謝 します.

\section{参考文献}

1) Ajiz, M. A. and Jenning, A. : A Robust Incomplete Choleski-Conjugate Gradient Algorithm, Int. J. Numer. Meth. Engng, Vol.20, pp. 949-966, 1984.

2) Arbenz, P., Hetmaniuk, U. L., Lehoucq, R. B. and Tuminaro, R. S. : A Comparison of Eigensolvers for Large-scale 3D Modal Analysis using AMG-Preconditioned Iterative Methods, Int. J. Numer. Meth. Engng, Vol. 64, pp. 204-236, 2005.

3) Bathe, K. J. : Finite Element Procedures in Engineering Analysis, Prentice-Hall, Englewood Cliffs, 1982.

4) Briggs, W. L., Henson, V.E. and McCormick, S. F. : A Multigrid Tutorial Second Edition, SIAM, Philadelphia, 2001.

5) Golub, G. H. and Underwood, R. : The Block Lanczos Method for Computing Eigenvalues, in Mathematical Software III, J.Rice, ed., Academic Press, New York, 1977.

6) Golub, G. H. and van Loan, C. F. : Matrix Computation, Johns Hopkins, Baltimore, 1983.

7) Hestenes, M. R. and Stiefel,E. : Methods of Conjugate Gradients for Solving Linear Systems, Journal of Research of the National Bureau of Standards, Vol.49, pp. 409-436, 1952.

8）柏木光博：一般化共役勾配法 (GCG 法)の有限要素法への適用に関する研 究 その 4 . 特異性判定修正式と平面 - 立体骨組の悪条件化数值実験, 日本建築学会構造系論文集, No. 521, pp. 185-192, 1999.7.

9）柏木光博：共役勾配法による最大あるいは最小固有解の一算定法，日 本計算工学会論文集，Vol.1，pp. 1-5， 1999.

10）柏木光博，共役勾配法による大次元スパース対称行列の固有解：日本応 用数理学会論文誌, Vol. 15, pp. 29-43, 2005.

11) Kashiwagi, M. : A Method for Determining Eigensolutions of Large, Sparse, Symmetric Matrices by the Preconditioned Conjugate Gradient Method in the Generalized Eigenvalue Problem, 日本建築 学会構造系論文集, No. 629, pp. 1209-1217, 2008.7.

12）柏木光博：ダブルシフト逆ベキ乗法によるスパース対称行列の中間固 
有解の一算定法, 日本応用数理学会論文誌, Vol. 19, pp. 23-38, 2009.

13）柏木光博：一般固有值問題におけるダブルシフト逆ベキ乗法によるス パース対称行列の中間固有解の一算定法, 構造工学論文集, Vol. 56B, pp. $445-451,2010$.

14）片山拓朗, 清田秀二, 柏木光博, 大脇信一, 平井一男 : 残差ベクトルを 用いた標準固有値問題の部分空間解法, 日本応用数理学会論文誌, Vol. 4, pp. 299-325, 1994.

15) Mei jerink, J. A. and van der Vorst, H. A. : Guidelines for the Usage of Incomplete Decompositions in Solving Set of Linear Equations as They 0ccur in Practical Problems, Journal of Computational Physics, Vol. 44, pp. 134-155, 1981.

16） 村田健郎, 小国力, 三好俊郎, 小柳義夫編著: 工学における数值シミュ レーション・スーパーコンピュータの応用，丸善，東京， 1988 .

17）成岡昌夫, 中村恒善共編, 骨組構造解析法要覧, 培風館, 東京, 1976 .

18) Nour-omid, B., Parlett, B. N. and Taylor, R. L. : Lanczos versus Subspace Iteration for Solution of Eigenvalue Problems, Int. J. Numer. Meth. Engng, Vol. 19, pp. 859-971, 1983.

19) Paige, C. C. : Computational Variants of the Lanczos Method for the Eigenproblem, J. Inst. Maths Applics, Vol.10, pp. 373-381, 1972.

20) Sleipen, G. L. G. and van der Vorst, H. A. : A Jacobi-Davidson Iteration Method for Linear Eigenvalue Problems, SIAM, Vol.17, pp.401-425, 1996.

21）Van der Vorst, H. A. ：超大型固有值問題の解法，応用数理，Vol.8, pp. 6-20, 1998.

22）矢川元基, 青山裕司 : 有限要素固有值解析 大規模並列計算手法, 森北 出版, 東京, 2001 .

（2010年10月 7 日原稿受理，2011年 3 月15日採用決定） 